\title{
A JOGI FELELŐSSÉG KIHÍVÁSAI A 21. SZÁZADBAN
}

\section{CHALLENGES OF LEGAL RESPONSIBILITY IN THE $21^{\text {ST }}$ CENTURY}

\author{
Nagy Marianna \\ habil. PhD, egyetemi tanár, Eötvös Loránd Tudományegyetem, Budapest \\ nagym@ajk.elte.hu
}

\section{ÖSSZEFOGLALÁS}

A felelősséggel számos tudományterület foglalkozik, egy jogász számára a felelősség mindig dogmatikai problémákat vet fel. A felelősség etikai, filozófiai vonatkozásai elválaszthatatlanok a jogi felelősség problematikájától, erről nagyon sokan írtak már. A tanulmány arra keresi a választ, hogy a jogtudomány a jogi felelősségi rendszer fejlesztésében milyen impulzusokat kaphat más tudományterületektől, elsősorban a közgazdaság-tudománytól, a kognitív idegtudományoktól, az evolúciós pszichológiától, a természettudományoktól. A társadalomtudományok közül az 1980-as évektől a közgazdaság-tudomány a racionális döntéselméleten (RDE) keresztül volt legnagyobb hatással a jogi felelősség fejlődésére. A hatás két szinten is megmutatkozott: egyrészt a jogi dogmatikában lett népszerű a joggazdaságtan művelése, másrészt indirekt módon a jogalkotóra hatott, a jogpolitikát határozza meg.

A modern orvosi diagnosztikai módszerek lehetővé tették, hogy az agyban lezajló döntési folyamatok egyre inkább láthatóvá váljanak. Az elvégzett kísérletek hatására új szociobiológiai irányzatok jelentek meg az emberi magatartások magyarázatára, amelyek a jogi felelősségre is kihathatnak. A kognitív idegtudományi és evolúciós pszichológiai eredmények arra utalnak, hogy az egységes döntési hatásmechanizmust feltételező jogi normák hatékonysága kétséges, mert másként kell és lehet befolyásolni a különböző döntési folyamatokat. Az idegtudományi megállapítások magyarázhatják a jogi szabályozás egyes kudarcait.

A jog mindig arra az emberképre reagál, amely az adott korban jellemző. A modern élettudományok alaposan átformálták az emberképet, de a jogi felelősség nem reagált erre. Az idegtudományi eredmények lehetővé teszik, hogy magyarázatot kapjunk a jogi szabályozás kudarcaira, és tovább differenciáljuk a jogi felelősséget, illetve meghatározzuk, hogy mely magatartásokat nem lehet jogi szankcióval befolyásolni, helyette jogon kívüli eszközöket kell alkalmazni.

\section{ABSTRACT}

A number of disciplines are concerned with responsibility, it always raises dogmatic issues for a jurist. Ethical and philosophical references of responsibility are inseparable from the issue of legal responsibility, as many have written about it before. The present discourse is seeking an answer to the question as to what impulses jurisprudence may receive from other disciplines, primarily from economic sciences, cognitive neuroscience, evolutionary psychology and natural sciences. From social sciences, economic sciences have had the most important impact on the 
evolution of legal responsibility since the 1980s through rational decision theory (RDT). This impact is reflected on two levels: on the one hand, the practice of legal economics became popular in the legal dogmatics, and, on the other hand, it had an indirect impact on the legislature, it determines the legal policy.

Recent medical diagnostical techniques have made it possible for the decision making processes of the brain to become more and more visible. Resulting from the experiments made, new sociobiological trends have risen to explain human behaviours which also have an impact on legal responsibility. Results in cognitive neurosciences and evolutionary psychology suggest that the effectiveness of legal norms presuming a uniform decision-making mechanism is dubitable because different decision-making processes can and should be influenced in different ways. Neuroscientific findings can explain some failures of legal regulation.

Law always reacts to the picture of human characteristics of the era. Recent life sciences have radically reshaped this picture but legal responsibility has not reacted to that. Neuroscientific results allow us to get an explanation as to the reasons of the failures of the legal regulation and to further differentiate legal responsibility as well as to define which behaviours cannot be influenced by legal measures and instead other means than legal instruments should be applied.

Kulcsszavak: jog, felelősség, kognitív idegtudományok, evolúciós pszichológia, racionális döntéselmélet, racionális választás

Keywords: law, responsibility, cognitive neuroscience, evolutionary psychology, rational decision theory, rational choice

A mindennapi életben a jog és a felelősség fogalma szorosan összefonódik, azonban a nem jogászok számára a két fogalom szinte azonos. A jogtudományban a felelősség mindig a jog érvényesítésének eszköze, és jogáganként eltérő szigorú belső dogmatikával rendelkezik. Az eltérő dogmatikák között azonban számos közös vonás is felfedezhető, hiszen mindegyik jogi konstrukció a jogsértések megakadályozásáról, a jogsértésekkel okozott károk kompenzációjáról, a represzszióról, a jogsértők szocializációjáról szól. A jogi felelősség kutatói mindig is élénk figyelmemmel kísérték a felelösséggel kapcsolatos más társadalomtudományi, humán tudományi megközelitéseket, mint például a felelősség etikai, filozófiai problémáit, hiszen az ezekre adott válaszkísérletek nagyon erős hatást gyakoroltak a jogi felelősség dogmatikájára is. A 20. század tudományos-technikai forradalma elsősorban a természettudományok és az élettudományok területén számos új eszközt adott a kutatók kezébe, amelyekkel sokkal többet tudhatunk meg az emberről, a döntési folyamatairól, az öt körülvevő világhoz való viszonyáról. Ebben a cikkben arra teszek kísérletet, hogy felvillantsak néhány olyan szempontot, amely azt bizonyítja, hogy a jogtudomány nemcsak a társadalomtudományok eredményeit tudja hasznosítani, hanem figyelemmel kell lennie a természettudományok, s ezen belül is a kognitív idegtudományok és az evolúciós pszichológia új eredményeire is. 
A jogi felelősség kutatóinak és a jogalkotónak is napi kudarcokat okoz, hogy bizonyos típusú jogsértéseknél nem müködik a jogi szabályozás, bármennyire is szigorítjuk a szankciókat, nem sikerül javulást elérni a jogkövetésben. Minden jogi szabályozás célja, hogy úgy hasson a címzettekre, hogy ha választás elé kerülnek, akkor a jogkövetés mellett döntsenek a jogsértés helyett. Lényegében tehát a jogi szabályozás azt a döntési folyamatot kívánja befolyásolni, amikor a címzett egy élethelyzetben mérlegeli a jogszerü és nem jogszerủ magatartás következményeit, és a jogszerüt választja. A különböző döntéselméletek eltérő magyarázatokat adnak a választás okaira és következményeire.

A jogi felelösségi konstrukciók az ún. szabálykövetö döntést (March, 2005, 19.) (rule based action) modellezik, amely azt feltételezi, hogy a döntési szituációt megértjük, és megkeressük hozzá az odaillő szabályt, majd alkalmazzuk a helyzetre. Ez a döntéselmélet a római jog óta müködik mind a közjog, mind a magánjog területén. A helyes döntés előfeltétele a szituáció kognitív feldolgozása, a szabály azonosítása, annak bensővé tétele és a cselekvés. Ha azonban nem müködik a szabálykövető modell, akkor célszerü nézőpontot váltani, és más tudományterületek döntéselméletei alapján vizsgálni a jogkövetö/jogsértő döntéseket, mert ha megtalálnánk azt a pontot, ahol elválik egymástól a két döntés, megtalálnánk azt a pontot is, ahol célzott szabályozással hatni tudunk a jogsértőkre.

Más tudományterületi impulzusok közül a jogi felelősségi dogmatikára és a jogalkotóra leginkább a közgazdaság-tudomány racionális fogyasztót modellező döntéselméletei ${ }^{1}$ (racionális döntéselmélet, rational decision theory, RDE) hatottak. Az RDE mint cselekvéselmélet a fogyasztót önérdekkövetónek tekinti, aki minden rendelkezésre álló információ alapján a számára a legnagyobb haszonnal járó lehetőséget választja. Az RDE-modellek a fogyasztói magatartást egyfajta költség/haszon logikában értelmezik. A mindenkori jogalkotó, lényegében az RDE logikája alapján ugyanígy gondolkodik. Azt feltételezi, hogy az egyre szigorodó szankciókkal józan belátásra bírja a jogsértőket, és ha számításba veszik, hogy a jogsértéssel realizálható előny kevesebb, mint a szankciókkal elérhető hátrány, akkor a költség/haszon elmélet alapján a jogkövetést választják. Ez a logika mozgatja például a büntetőjogban a „három csapás” szabályát, vagy az egyre magasabb összegủ bírságok szabályozását a közigazgatási jogban. Mégsem müködik jobban a jogi felelösség, nem lett jobb a jogkövetés aránya. Ennek alapvetően az az oka, hogy az RDE-modellek (melyeknek a közgazdaság-tudományban is számos változatuk és kritikájuk van) nem minden jogsértésre alkalmazhatók egyforma hatékonysággal. A jogi szabályozásban jól használhatók az RDE-modellek például a szerződési szankciók területén, de megbuknak a közjogi szabályozás-

${ }^{1}$ Az RDE-modelleknek könyvtárnyi szakirodalmuk van, meghivatkozni ehelyütt lehetetlen. Lásd a közgazdasági irodalomból Ronald Coase, Amos Tversky és Daniel Kahnemann, Herbert A. Simon műveit, a joggazdaságtani megközelítésekből Michael Posner müveit. 
ban (Nagy, 2010). Nem múködnek, mert egy hipotetikus, átlagos jogsértőt feltételeznek, és minden jogsértő más, és mert csak a célracionális jogsértésekre igaz a modell, de a jogsértések nagy részét nem célracionálisan követjük el.

Max Weber nyomán (Weber, 1987, 53.) a jogsértéseket négy csoportra oszthatjuk: célracionális, értékracionális, emocionális és tradicionális jogsértések. Célracionális jogsértésnél mindig valamilyen jól definiált célt, hasznot szeretnénk elérni, az értékracionális jogsértéseket azonban valamilyen etikai, vallási, esztétikai önértékbe vetett hit befolyásolja. Az emocionális jogsértéseink indulati, érzelmi cselekvések, míg a tradicionális jogsértéseket a szokások határozzák meg. Ha tehát nem müködik a közgazdasági döntéselmélet, érdemes megnézni, hogy más tudományterületek - elsősorban a természettudományok - döntéselméletei alkalmazhatók-e a jogi dogmatikában.

A 20. század utolsó két évtizedében viharos fejlődésnek indult a képalkotó diagnosztika, az EEG mellett megjelentek a CT, az fMRI, a PET, az infravörös spektroszkópia eszközei, amelyek lehetővé tették az agykutatók számára, hogy korábban elképzelhetetlen részletességgel tegyenek láthatóvá egyes emberi döntési folyamatokat. A kognitív idegtudományi kutatások hihetetlen eredményeket mutatnak fel, teljesen átalakítják az emberi gondolkodásról alkotott képünket. Ezek az eredmények kihatnak a társadalomtudományokra is, autonóm tudományterületként jelent meg a szociobiológia, amely az emberi társas viselkedés biológiai alapjait kutatja, másfajta kauzalitás alapján magyarázza a társas viselkedést. Ezek a szociobológiai magyarázatok neurojog elnevezéssel önálló irányzattá váltak a jogtudományi kutatásokban, és a viselkedő ember helyett a megismerő ember belső idegrendszeri folyamatait elemzik. A jogi felelősség szempontjából adekvát kérdésként merül fel: van-e különbség a jogkövető és a jogsértő döntés megszületésének mechanizmusában? Van-e összefüggés az agy funkcionális és/ vagy strukturális deficitje és a jogsértő magatartások között? Ha igen, akkor milyen összefüggésekre tudunk hatni ezek közül?

A szándékos jogsértéseket a jogi felelősségi konstrukciók mindig külön csoportként kezelik, és azzal a hipotézissel élnek, hogy a címzettek a jogszabályban foglalt parancsot kognitív eszközökkel feldolgozzák, és annak megfelelően cselekednek. Ebben a hipotézisben a szándék nem egyszerủen időben előzi meg a cselekvést, hanem annak egyenesen előfeltétele, a jogsértő szabad akaratából választja a jogsértést. A kognitív idegtudományi vizsgálatok azonban alapjaiban cáfolják a jogtudományi modellt, mert elválasztják egymástól a szándékot és a cselekvést, és nem tételeznek fel közöttük ok-okozati összefüggést! Benjamin Libet és Susan Greenfield kognitív idegtudományi kísérletei azt bizonyítják, hogy a szándék nem előzi meg időben a cselekéseinket, sőt jelentős csúszással követi azokat. Libet híres kísérlete (Greenfield, 2000, 182-183.), amelyben azt vizsgálta, hogy mennyi idő alatt észleli az agy a bejövő ingereket, az igazolták, hogy a frontális lebenyben kb. 500 millisecundummal később tudatosodik a tüszúrás érzete, 
mint ahogyan az agy más területei észlelik a tủszúrást. Greenfield saját magán végzett kísérlete (Greenfield, 2000, 183-184.) arra irányult, hogy ha elszánjuk magunkat egy cselekvésre, akkor a szándék vagy a cselekvés egymáshoz való időbeli viszonya hogyan alakul. Ehhez elektródákkal mérték az agyi aktivitását akkor, amikor azt a feladatot kapta, hogy nyomjon meg egy gombot, de mielőtt megnyomná, elöre jelezze, hogy meg fogja nyomni. A kísérlet azt a megdöbbentő eredményt hozta, hogy a cselekvésre irányuló döntés a frontális lebenyben 1 másodperccel azután született meg, hogy a mozgásért felelös szupplementer motoros area megkezdte a felkészülést a cselekvésre! Vagyis a szándékos cselekményeket mintegy 1 másodperccel megelőzi egy EEG-vel mérhető válasz - az ún. készenléti potenciál - a szupplementer motoros areában, amely a cselekvések kiválasztásával kapcsolatos folyamatok agyterülete. Tehát a szándék tudatos megjelenése a cselekvés kiválasztása után jelenik meg, vagyis a szándék élménye független a cselekvés kiválasztásától! Ez a felfedezés felboritja a szándékot elöfeltevésként kezelö jogi dogmatikát, de magyarázatot ad a begyakorlott, rutinszerü jogsértések elkövetésére. Ezen eredmények alapján a szokásszerü, tradicionális jogsértéseinket azért tudjuk kognitívan nehezen uralni, mert mire tudatosodik a cselekvésünk, addigra régen elkövettük azt. Úgy is fogalmazhatunk, hogy lekéssük a saját szándékunkat. Ugyanakkor a római jog óta müködő hipotézisünkkel kapcsolatban felmerül a kérdés: hol a helye a jogi felelősségnek, ha nem igaz, hogy a szándék előfeltétele a jogsértésnek? Lényegében a szabad akarat kérdéséröl van szó. Libet és Greenfield kísérletei azt igazolják, hogy az ember nem annyira racionális lény, hanem inkább utólag racionalizáló lény. Lehet-e a kognitív idegtudományi eredmények következménye az, hogy ki kell dobni a teljes felelősségi dogmatikát? Bár alapjaiban rengetik meg az új ismeretek a jogtudományi modellünket, mégsem hinném, hogy emiatt el kellene felejtenünk a szándékosságon alapuló felelösségi konstrukciókat. Mert igaz ugyan, hogy a homo sapiens utólag racionalizáló lény, de mindenki ugyanannyira utólag racionalizáló lény. A mérce tehát egyenlően hibás mindenkire vonatkozóan, és több mint kétezer éve azért mégiscsak betöltötte a reguláló szerepét, még ha nem is azzal a hatásfokkal, amit reméltünk. Ugyanakkor ezek az eredmények hozzásegíthetik a jogi dogmatikát ahhoz, hogy kijelöljük a szándékosságon alapuló jogi felelősségi konstrukciók hatóképességének határait, meghatározzuk azokat a cselekvéseket, ahol biztosan nem müködnek a szándékosság-gondatlanság klauzulái. A tradicionális, szokásszerủ jogsértések esetén kizárhatjuk ezeket a dogmatikai modelleket, helyette más jogi vagy jogon kívüli eszközöket kell keresnünk.

Mi a helyzet az érzelemvezérelt, emocionális jogsértéseinkkel? A jogtudományban élesen elválasztjuk az érzelmek által dominált jogsértéseket, néha súlyosbító, néha enyhítő körülményként tekintünk az érzelmekre. Gondoljunk csak az erős felindulásból elkövetett vagy az aljas indokból elkövetett megkülönböztetésekre, vagy arra, hogy bizonyos beszúkült tudatállapotok mentesíthetnek a felelős- 
ség alól. A kognitív idegtudományi vizsgálatok arra utalnak, hogy a szándékos és emocionális magatartás-vezérlések sokkal szorosabban összefonódnak, még akkor is, ha más-más agyterületek aktivizálódnak a döntési folyamat során. Antonio R. Damasio híres ún. Iowa-kártyakísérleteiben (Damasio, 1996a) a játékosok piros és kék kártyacsomagokból lapokat húztak, és a résztvevők minden húzásnál esetlegesen jutottak nyereséghez vagy veszteséghez, de ezt nekik elöre nem mondták meg. A kísérlet során egy olyan, a hazugságvizsgálatnál használt műszerhez hasonló müszerre kapcsolták őket, mely a bőr vezetőképességének változását méri. A legtöbb játékosnak kb. ötven lap után az az érzése támadt, hogy a piros kártyacsomaggal baj van, és további harminc lap húzása után azt is pontosan meg tudta mondani, hogy mi a hiba. Ez magyarázható lenne a logikával, de érdekes módon már a játék megkezdése után tíz lappal izzadni kezdett a tenyerük, ha a piros kártyacsomaghoz nyúltak. Vagyis az agyuk egy része tudta, hogy a piros csomag rossz választás, és kezdte kerülni azt, annak ellenére, hogy még további negyven kártyán keresztül nem fogták fel tudatosan a problémát, és az azt követő harminc kártyán keresztül nem tudtak magyarázattal szolgálni. Vagyis mielőtt megfogalmazták volna a problémát, és mielőtt választ adtak volna a problémára, $k b$. fél óra után a játékosok intuitív módon elkezdték a mérsékelt nyereséget nyújtó kék kupacot preferálni. Érdekes módon a sérült prefrontális kéreggel élő kísérleti alanyok is rájöttek végül, hogy a piros csomag hátrányos, de náluk nem mérték a bör vezetőképességének a változását, csak logikailag jutottak erre a következtetésre.

Damasio szerint a nyereséggel kapcsolatos érzelmi asszociációk (Damasio, 1996b), illetve a veszteséghez kötődő érzelmek a tudatalattiban bújnak meg, és apró kémiai változásokat idéznek elö (ezek az ún. szomatikus markerek). Általában nem vesszük észre a szomatikus markereket, de ha tétje van a döntésünknek, a tudatukra ébredünk. Damasio szerint a szomatikus markerek tulajdonképpen a zsigeri környezetből érkeznek, mert a negatív döntések rossz érzéseket, testi tüneteket okoznak az embereknél, és ezeket idézi fel az agyunk, hogy megvédjen bennünket a jövőbeli kedvezötlen döntésektől. Valójában tehát a régi rossz döntésünk által kiváltott fizikai diszkomfortot érzékeli az agy, anélkül hogy az tudatosodna. A szomatikus marker hipotézis szerint a homloklebeny alsó-belső része a ventromediális prefrontális kortex (VMPFC) érzékeli ezt a jelzést, mert a VMPFC hátsó részéhez futnak azok az idegpályák, amelyek az érzelmi, vegetatív müködések központjaiból (amigdala, hipotalamusz, limbikus striátum, agytörzs) indulnak. Greenfield ebből azt a következtetést vonja le, hogy „valójában a rejtett érzelmek irányítanak bennünket akkor is, amikor azt gondoljuk, hogy logikusan cselekszünk" (Greenfield, 2000, 118.). Bereczkei Tamás szerint (Bereczkei, 2008) a szomatikus markerek is rendelkeznek bizonyos kognitív tartalommal, hiszen valószínüleg csökkentik a lehetséges alternatívák számát, és ezzel növelik a döntési folyamat pontosságát és hatékonyságát. A szomatikus marker hipotézis nagyon hamar népszerüvé vált, bár rengetegen vitatják, nem is annyira ma- 
gát a megállapítást, mint inkább a belőle levont következtetéseket. Ha igaza van Greenfieldnek, akkor az emocionális döntések uralják az életünket, és viszonylag kis esély van arra, hogy észérvekkel hassunk a döntéshozóra, vagy a szocializáció egyéb eszközeit alkalmazzuk. De vajon mindenre kiterjeszthető-e a szomatikus marker hipotézis? Hiszen mindannyian átéltük már azt is, hogy rossz érzésünk volt ugyan egy-egy döntésünkkel kapcsolatban, de annak ellenére döntöttünk, és idővel a döntésünk jónak bizonyult. Ezekben az esetekben nyilván valamilyen kognitív folyamat eredményeként felülírjuk a saját szomatikus markereinket. A jogi felelősségre vonatkozóan azonban a szomatikus marker hipotézis esetleg magyarázatul szolgálhat azon jogsértésekre, amelyeknek az ismétlödését (büntetöjogban a visszaesést) nem tudjuk magyarázni, és bármilyen mértékben is emeljük a szankciókat, az ismétlödési arányokon nem sikerül javitani.

Az agyi képalkotó módszerek eddig bemutatott felhasználási területei részben a célracionális cselekvések, részben az alapvető érzelmek detektálását szolgálták. A jogérvényesülést azonban csak részben vizsgálhatjuk etikailag színtelen, technikai normák érvényesülésén, a jog számos esetben valamilyen értékracionalitást vár el, vagy értékracionalitást is elvár a norma címzettjétől. Adódik a kérdés, hogy van-e különbség a célracionális és az értékracionális (vagy másként morális) döntési mechanizmusok között, illetve van-e az agynak morális központja? A morális döntések vizsgálata önmagában is rendkívül izgalmas kérdés, és annak teljes bemutatása meghaladja e tanulmány kereteit. A jogtudomány problémáinak vizsgálatában Kéri Szabolcs munkásságára (Kéri, 2008) támaszkodva indulhatunk el azzal, hogy ezek csupán kiindulópontok, hiszen rengeteg újabb kérdést involválnak. A morális döntések meghozatala során több agyterület különböző mértékủ aktivitása mérhető a modern képalkotó eljárásokkal. Elsősorban a prefrontális kortexünket dolgoztatjuk a morális döntéseknél, de szerepet kaphatnak a törzsdúcok és a dorzolaterális anterior cingulum is. Agyunkban tehát máshol és más folyamat nyomán születik meg a morális döntés, mint a célracionális és az emocionális döntés. Söt, a vizsgálatok arra utalnak, hogy más agyterületek aktiválódnak, ha a saját és más területek, ha más morális problémáit oldjuk meg. Ugyancsak más mechanizmusban hozunk döntést, ha utilitárius és ha nem utilitárius módon oldjuk meg a problémát. Az előbbi esetében az anterior prefrontális kortex 10-15\%-kal nagyobb aktivitást mutat. Kéri több hipotézist is felsorakoztat a morális döntések neurobiológiai magyarázatára, a jogi felelösség problémáira viszont egyik sem ad maradéktalan választ, de mindegyikben vannak megfontolandó elemek. Ehelyütt nincs mód a részletes ismertetésükre, de egy következtetést biztosan levonhatunk a különböző döntési folyamatok alapján. Nem müködik az a jogdogmatikai feltevés, hogy homogén döntési folyamatot tételezünk fel minden jogsértésre, homogén hatásmechanizmusú normákkal akarunk eredményt elérni eltérö hatásmechanizmusú döntési folyamatokban. Ez a leegyszerüsítö modell okozhatja számos szabályozási kudarcunkat. 
A kognitív idegtudományi modellek mellett jelentősen módosíthatják a jogi felelősségről alkotott képünket az evolúciós pszichológia eredményei. A jogtudomány elsősorban a behaviorista pszichológia premisszáira épít, ezeket az eredményeket sikeresen építette be a dogmatikai konstrukcióiba. Ez azonban nem tesz különbséget a jelenségszintü, az annál kisebb vagy nagyobb egységekre irányuló tudatosság között. Az evolúciós pszichológia - a kognitív idegtudományi kutatások eredményeire is építve - olyan új nézőpontot kínál az emberi magatartások magyarázatára, amely alapjaiban különbözik a behaviorista magyarázattól (Bereczkei, 2008). Az evolúciós pszichológia szerint ugyanis az emberi magatartásokat (vagy legalábbis azok egy részét) olyan pszichológiai programok vezérlik, amelyek évmilliókon keresztül a biológiaihoz hasonló evolúción mentek keresztül, és amelyek az emberi faj környezethez való alkalmazkodását, végső soron az életben maradását segítették elő, és ezek a programok - éppen az életben maradást segítő voltuk miatt - kódoltak az emberi agyban. Ez a megközelítés minden ponton eltér a jogtudományi modelljeinktől. Míg a jogi felelősségi konstrukcióink az emberi cselekvés közvetlen okait (proximatív okok) kutatják, az evolúciós pszichológia a viselkedés távoli okaival (ultimatív okok) magyarázza a magatartást. Az ultimatív magyarázat mindig arra keresi a választ, hogy mennyiben szolgálta az életben maradást az adott magatartás. Ez a megközelítés a kauzalitás teljesen más szintjén ad magyarázatot egyes döntéseinkre. Az evolúciós pszichológia tehát az ember adaptációs képességével magyarázza (adaptacionizmus) az egyes magatartások sikerességét vagy kudarcát. Az egyik legnagyobb eltérés a két megközelítés között a változás idősíkjában van. A társadalomtudomány - és a jogtudomány különösen - az azonnali vagy legalábbis rövid időn belül bekövetkező változásokat várja el, az evolúciós nézőpont évmilliókban esetleg évezredekben gondolkodik. A mai nézőpontból diszfunkcionálisnak tekintett magatartásminták egykor funkcionálisak lehettek, ám a környezet és a kultúra változása folytán diszfunkcionálissá váltak. Mivel azonban az elmúlt 10-15 ezer évben a társadalmi evolúció alaposan megszaladt a biológiai evolúcióhoz képest, ami sikeres életben maradást garantált kiszolgáltatva a természeti körülményeknek a vadászó-gyüjtögető életmód során, az ma könnyen lehet, hogy az ellenkezőjére fordul. Az evolúció során kialakult mentális algoritmusok ellentmondásba kerülhetnek a modern társadalom elvárásaival. Az üss vagy fuss magatartásvezérlés müködött az őskorban, de nem sok jóval kecsegtet a tömött 6-os villamoson vagy egy (túl) szabályozott iskolai közösségben. A másik jelentős elérés a jogdogmatikai és az evolúciós pszichológiai magyarázat között, hogy míg az előbbi univerzális tanulási mechanizmusokat feltételez, az utóbbi ún. moduláris tanulással magyarázza az emberi cselekvéseket. Azaz, a jogtudomány azt feltételezi, hogy bármit képesek vagyunk megfelelő kondicionálás alapján elsajátítani, míg az evolúciós pszichológia álláspontja szerint a megismerés-tanulás kisebb, egymástól elkülönült modulokban történik, és az emberi elme specializálódott mentális algoritmusok 
összessége. Mivel maga a modularitás az egyik legvitatottabb állítása az evolúciós pszichológiának, ezért a jogtudományi problémák megoldására célszerủ Bereczkei Tamás magyarázatát elfogadni, aki szerint valószínü, hogy az emberi megismerést mozaikos szerkezet jellemzi. Azaz vannak olyan magatartásaink, amelyeket univerzális tanulással, másokat modulárisan sajátítunk el. Ez a mozaikosság adhat mozgásteret a jogi felelősségnek, már csak azt kellene tudnunk, hogy milyen magatartásaink tartoznak az egyik, illetve a másik vezérlés alá. Ha ugyanis vannak modulárisan vezérelt magatartásaink, akkor ott nem hatnak az univerzális tanulásra épített jogi normák.

Milyen hatással lehetnek a kognitív idegtudományi és evolúciós pszichológiai kutatási eredmények a jogi felelősség dogmatikájára a 21. században? A szakirodalom nagyon megosztott ebben a kérdésben. Az ún. brain lesion studies képviselői szerint, mivel direkt összefüggés van az agyi struktúrák és funkciók között, a szabad akarat lényegében a kognitív struktúrák illúziója. A jogi felelősség pedig ettől az illúziótól függ. Vannak, akik határozottan elutasítják a két tudományterület kapcsolódását, arra hivatkozva, hogy a két tudományterület más kérdésre keresi a választ, és mindaddig, míg a képalkotó eljárások nem képesek teljes alternatíváját adni a pszichológiai funkciók magyarázatainak, addig a kognitív idegtudományi eredmények irrelevánsak.

Jómagam a mérsékelt optimista álláspontot képviselem, és azt vallom, hogy az új természettudományos felfedezésekre igenis reagálnia kell a jogtudománynak. Bizonyosan nem tartható a jogi felelősségnek az a feltevése, hogy az emberek minden cselekedetük minden faktorát képesek befolyásolni. Vannak befolyásolható és nem befolyásolható faktorok, de a kettő közötti határvonal folyamatos mozgásban van, és a rögzítéséhez a természettudományi kutatások járulhatnak hozzá. A jogi felelősség hatékonysága akkor javítható, ha a szabályozás a befolyásolható faktorokra irányul, és nem általában az emberi magatartásra. Ezért a jövőben a jogi szabályozás korlátait nem csupán a társadalomtudományok, hanem a természettudományok is kijelölik. Sokkal reálisabbak lehetnek az elvárásaink a jogi felelősség hatókörével kapcsolatban, megmagyarázhatjuk a kudarcainkat. A természettudományos eredmények adhatnak magyarázatot arra, hogy miért nem múködik a mégoly szigorú jogi szabályozás sem például a futballhuliganizmus vagy az iskolai erőszak regulációjában. Ezekben az esetekben jogon kívüli eszközöket kell találnunk, az ún. szituatív szabályozás eszközével nem a jogsértést kell megbüntetnünk, hanem olyan helyzetet kell teremteni, hogy ne követhessék el a jogsértést. Mire nem alkalmasak az idegtudományi eredmények? Arra bizonyosan nem, hogy megjósoljuk a bünösségre vagy a veszélyre való hajlamosságot. Nem tudjuk megjósolni, hogy kiböl lesz jogsértő, és nem alkalmas a büntetések hatékonyságnak előre jelzésére sem. De a jogtudomány mindig arra az emberképre reagál, amely az adott korszakot jellemzi, és a 21. század emberképe jelentősen átalakult a természettudományi kutatások eredményeképpen. 
A jogtudomány nem teheti meg, hogy ezeket az eredményeket figyelmen kívül hagyja! Annál is inkább lépnie kell, mert ha a jogi dogmatika nem értékeli ezeket a kutatásokat, és nem építi be a saját felelősségi modelljeibe, a joggyakorlat fogja kikényszeríteni, hogy ezeket az eredményeket felhasználja a jogalkalmazó. A pragmatizmusáról híres amerikai jogrendszerben már megjelentek a tárgyalótermi felhasználások, anélkül hogy a tudományos communis oppinio kialakult volna a felhasználhatóságot illetően. Vannak vállalkozások, amelyek hazugságvizsgálatokat végeznek arra alapozva, hogy a középső és belső girusz eltérő képet mutat hazugság és igazmondás esetén. Az ún. brain finger printer azokra az emlékképekre adott agyi válaszokat vizsgálja, amelyekre csak a bünös elkövető emlékezhet. A biztosítási iparágban óriási jövő elé néz az ún. fájdalommátrix, vagyis olyan agyi térképek készítése, amelyek a fájdalomra való reakciókat rögzítik. De minden tárgyalótermi felhasználás csak azt a pillanatot rögzíti, amikor vizsgálják az alanyt, arra nem ad választ, hogy mit gondolt az elkövetés pillanatában. Mint ahogyan arra sem, hogy mi van, ha elhiszi, hogy elkövette, de valójában nem tette azt. Éppen ezért a jogtudománynak vigyázó szemeit ma már nemcsak a társadalomtudományok egyéb területeire, hanem a természettudományokra is vetnie kell, és újra kell definiálni az alapkategóriáit a 21. század ismereteinek megfelelöen.

\section{IRODALOM}

Bereczkei T. (2008): Evolúciós pszichológia. Budapest: Osiris Kiadó

Damasio, A. (1996a): Descartes tévedése - Értelem, érzelem és az emberi agy (ford. Pléh Cs.). Budapest: Aduprint Kiadó

Damasio, A. (1996b): The Somatic Marker Hypothesis and the Possible Functions of the Prefrontal Cortex. Proceedings of the Royal Society, 351, 1413-1420.

Greenfield, S. (2000): Agyunk titkai - betekintés érzelmeink, ötleteink világába. Budapest: Alexandra Kiadó

Kéri S. (2008): A morális döntések neurobiológiai vonatkozásai. Magyar Pszichológiai Szemle, LXIII., 251-264.

March, J. G. (2005): Szervezeti tanulás és döntéshozatal. Budapest: Alinea Kiadó

Nagy M. (2010): Interdiszciplináris mozaikok a közigazgatási jogi felelösség dogmatikájához. Budapest: ELTE Eötvös Kiadó

Weber, M. (1987): Gazdaság és társadalom - A megértő szociológia alapvonalai (ford. Erdélyi Á.). Budapest: Közgazdasági és Jogi Könyvkiadó 